\title{
Differences in Seedling Growth of 23 Creeping Bentgrass Cultivars under Polyethylene Glycol-induced Drought Conditions
}

\author{
Qi Zhang ${ }^{1}$, Liqi Yang, and Kevin Rue
}

AdDitional IndeX wORDs. Agrostis stolonifera turfgrass, specific root length

Summary. Drought is the most important abiotic stress in crop production including turfgrass management. Using drought tolerant plants can help minimize stress damage. In this study, 23 commercially available cultivars of creeping bentgrass (Agrostis stolonifera) were evaluated for their responses to drought stress that was induced by polyethylene glycol (PEG) 6000 in a hydroponic system during the seed germination and seedling growth stage. In such a system, water potential was adjusted to 0.0 (the control), -0.3 , and $-0.6 \mathrm{MPa}$ to mimic the drought condition. The absolute water content (AWC), shoot dry weight (SDW), root dry weight (RDW), longest root length (LRL), specific root length (SRL), and root-toshoot dry weight ratio (RSR) in the plants grown for 4 weeks in the treatment were determined. Results showed that SDW and LRL were unaffected by drought; however, RDW and RSR increased, whereas SRL and AWC were reduced under drought. Among the 23 creeping bentgrass cultivars evaluated, Independence and Crystal Bluelinks had a higher turfgrass performance index (TPI), which represented the number of times a cultivar ranked in the top statistical group across all parameters. The results suggest that 'Independence' and 'Crystal Bluelinks' may be more adapted to drought than the other cultivars at the seedling stage.

$\mathrm{C}$

reeping bentgrass is widely used on golf course putting greens and fairways because of its fine leaf texture, high density, and excellent tolerance of low mowing height (Christians, 2011). However, frequent irrigation is required to retain its playability and aesthetical qualities under intensive use. Limited water resources and rapid suburban expansion have led to restricted irrigation in many communities. Deficient irrigation causes reduced turfgrass quality and even plant death when drought stress is severe. In addition to plant damage, prolonged drought can cause a severe economic impact on the turfgrass industry. For example, during a 2-month major drought in conjunction with watering restrictions in New Jersey in 1999, the local turfgrass industry lost $\$ 150$ million in revenue (Govindasamy et al., 2007).

It has been reported that inter and intraspecific differences in drought tolerance in turfgrass exist. Fry and Huang (2004) reported that

Department of Plant Sciences, North Dakota State University, P.O. Box 6050, Dept. \#7670, Fargo, ND 58108

We would like to thank U.S. Golf Association and ND Hatch project no. 01576 for funding this project.

${ }^{1}$ Corresponding author. E-mail: qi.zhang.1@ndsu. edu.

https://doi.org/10.21273/HORTTECH03990-18 tall fescue (Festuca arundinaceae) showed very good overall drought tolerance, whereas kentucky bluegrass (Poa pratensis) was rated good, and creeping bentgrass and perennial ryegrass (Lolium perenne) were rated fair in drought tolerance. Salaiz et al. (1991) indicated that genetic variations led to the differences in evapotranspiration $(\mathrm{ET})$ rates and rooting depths in 10 creeping bentgrass cultivars. Of the 10 cultivars, Penncross showed the highest potential for drought tolerance because of its deep rooting habit and the highest ability to conserve water (i.e., low ET), whereas others only possessed one of the two aforementioned characteristics. Another study of drought tolerance in bentgrass cultivars showed that Penn A-4, Independence, and L-93 were more tolerant than Penncross, Putter, and Declaration (McCann and Huang, 2008).

In the last decade, a few improved creeping bentgrass cultivars have been released with high competitiveness over annual bluegrass (Poa annua), such as T-1 and Alpha (Brede, 2007) and high overall quality, such as 007 and Tyee (National Turfgrass Evaluation Program, 2008), but very limited information on their drought tolerance is available. Turfgrass is more likely to experience drought stress at the seedling stage than the vegetative growth stage because of limited root system during the initial growth (i.e., seedling stage) (Reicher et al., 2006). Low drought tolerance at the seedling stage may easily result in failure of turfgrass establishment (Chai et al., 2006). The objective of this study was to compare the drought tolerance of 23 commonly used creeping bentgrass cultivars at the seedling growth stage.

\section{Materials and methods}

Twenty-three creeping bentgrass cultivars used in this study are listed in Table 1. Seeds were germinated in a hydroponic system, following the method of Zhang et al. (2011). Briefly, 23 cells $(6 \mathrm{~cm}$ diameter) were created on a $50 \times 30 \times 2-\mathrm{cm}$ foam plate (one cell for each cultivar). Two layers of plastic screen were glued on the bottom of the plate. Two hundred fifty milligrams of seeds of one cultivar were placed in one cell. Each plate was floated in PEG-6000 (VWR International, Batavia, IL) solutions at $0.0 \mathrm{MPa}$ [0\% PEG-6000 (control, nonstressed)], $-0.3 \mathrm{MPa}(15 \% \mathrm{PEG}-$ $6000)$, or $-0.6 \mathrm{MPa}$ (22.5\% PEG6000) (Michel and Kaufmann, 1973). As seeds germinated, roots penetrated through the plastic screen into the PEG-6000 solution. No Hoagland's solution (Hoagland and Arnon, 1950) was added to the PEG-6000 solutions because nutrients are not required for turfgrass germination for up to 5 weeks (Horst and Taylor, 1983). The hydroponic system was constructed in a controlled culture room with an air temperature of $25 \pm 2{ }^{\circ} \mathrm{C}$ under fluorescent light $\left(36 \mu \mathrm{mol} \cdot \mathrm{s}^{-1} \cdot \mathrm{m}^{-2}\right)$ with a 12-h photoperiod. Seeds were maintained in the hydroponic system for 4 weeks, during which

\begin{tabular}{llll}
\hline $\begin{array}{l}\text { Units } \\
\text { To convert U.S. to SI, } \\
\text { multiply by }\end{array}$ & U.S. unit & SI unit & $\begin{array}{l}\text { To convert SI to U.S., } \\
\text { multiply by }\end{array}$ \\
\hline 0.1 & bar & $\mathrm{MPa}$ & 10 \\
2.54 & inch $(\mathrm{es})$ & $\mathrm{cm}$ & 0.3937 \\
28,350 & $\mathrm{oz}$ & $\mathrm{mg}$ & $3.5274 \times 10^{-5}$ \\
$\left({ }^{\circ} \mathrm{F}-32\right) \div 1.8$ & ${ }^{\circ} \mathrm{F}$ & ${ }^{\circ} \mathrm{C}$ & $\left({ }^{\circ} \mathrm{C} \times 1.8\right)+32$
\end{tabular}


the hydroponic system was constantly aerated to maintain the solubility and availability of oxygen (Mexal et al., 1975 ).

The experiment was arranged in a split-plot design with the drought level (i.e., PEG-6000 solution) being the whole-plot factor and cultivar being the subplot factor. The wholeplot factor was arranged in a randomized complete block design with three replications. Shoots and roots were harvested separately when the experiment was ended at week 4. Shoot fresh weight and the LRL were recorded immediately after the harvest. SDW and RDW were determined after tissues were oven-dried at $65{ }^{\circ} \mathrm{C}$ for $24 \mathrm{~h}$. RSR was then calculated. AWC was determined as the difference between shoot fresh and dry weights (Hughes et al.,
1970). SRL was the ratio between LRL and RDW (Pérez-Harguindeguy et al., 2013). To avoid genetic differences in seed size, seedling vigor, and growth habit in different cultivars, data of the control treatment were standardized as $100 \%$ of each cultivar and the data at -0.3 and $-0.6 \mathrm{MPa}$ were presented as percentage of the control within each cultivar (Horst and Dunning, 1989). Data were then subjected to PROC MIXED (SAS version 9.4; SAS Institute, Cary, NC) with drought and cultivar being the fixed effects and replicate and replicate $\times$ drought being the random effects. Means were separated with the PDIFF statement of the least square means at $P \leq 0.05$ (SAS version 9.4). Correlation coefficient analysis $(r)$ was performed using PROC CORR (SAS version 9.4) to examine the relationships among the growth parameters. TPI was generated for each cultivar, representing the number of times a cultivar occurred in the top statistical group (Wherley et al., 2011).

\section{Results}

SDW was unaffected by the drought condition (Tables 2 and 3); however, significant differences in SDW among bentgrass cultivars were observed (Table 2). 'Bengal' showed the highest SDW (170.9\% of the control), whereas '007' had the lowest SDW (67.1\% of the control) (Table 4 ). The average SDW of 'Kingpin', 'Crystal Bluelinks', 'Independence', 'Declaration', and 'Pin-up' was $132.0 \%$ of the control, which was $86.2 \%$ higher than that of 'Penncross', 'Memorial', and ' 007 ' (average $=70.9 \%$ of the control).

Table 1. Seed source, cultivars name, and year of release of the 23 commercially available creeping bentgrass cultivars used in the study.

\begin{tabular}{ll}
\hline Seed source & Cultivars name and yr of release \\
\hline Barenbrug USA (Tangent, OR) & Bengal (2002) \\
J.R. Simplot (Liberty Lake, WA) & Putter (1989), South Shore (1992), L-93 (1995), Alpha (2004), T-1 (2004), \\
& V8 (2010) \\
Lebanon Seaboard Co. (Lebanon, PA) & Independence (2002), Declaration (2005) \\
DLF Pickseed USA (Halsey, OR) & Cobra 2 (2008) \\
ProSeeds Marketing (Jefferson, OR) & Kingpin (2006), Pin-up (2010) \\
Seed Research of Oregon (Tangent, OR) & 007 (2006), MacKenzie (2006), SR 1150 (2006), Tyee (2006), \\
& Focus (2012) \\
Tee-2-Green (Hubbard, OR) & Penn A-1 (1995), Penn A-4 (1995), Penncross (1955), Pennlinks II (2004), \\
& Crystal Bluelinks (2007) \\
The Scotts Co. (Marysvile, OH) & Memorial (2004) \\
\hline
\end{tabular}

Table 2. Analysis of variance of creeping bentgrass cultivars grown under drought at the seedling stage. Data at -0.3 and $-0.6 \mathrm{MPa}$ were presented as percentage of the control $(0.0 \mathrm{MPa})$ within each cultivar. ${ }^{\mathrm{z}}$

\begin{tabular}{|c|c|c|c|c|c|c|c|}
\hline $\begin{array}{l}\text { Source of } \\
\text { variation }\end{array}$ & df & $\begin{array}{l}\text { Shoot } \\
\text { dry wt }\end{array}$ & $\begin{array}{c}\text { Absolute water } \\
\text { content }\end{array}$ & Longest root length & $\begin{array}{c}\text { Root } \\
\text { dry wt }\end{array}$ & $\begin{array}{c}\text { Specific root } \\
\text { length }\end{array}$ & $\begin{array}{l}\text { Root:shoot } \\
\text { dry wt ratio }\end{array}$ \\
\hline Drought (D) & 2 & NS & * & NS & * & * & * \\
\hline Cultivar (C) & 22 & * & * & * & * & NS & * \\
\hline $\mathrm{D} \times \mathrm{C}$ & 44 & NS & NS & NS & NS & NS & NS \\
\hline
\end{tabular}

${ }^{\mathrm{z}}$ Drought was induced by polyethylene glycol 6000 at $0.0,-0.3$, and $-0.6 \mathrm{MPa} ; 1 \mathrm{MPa}=10 \mathrm{bar}$.

*, ss Significant and no significant differences at $P \leq 0.05$.

Table 3. Relative seedling growth of 23 creeping bentgrass cultivars as affected by drought. Data at -0.3 and $-0.6 \mathrm{MPa}$ were standardized as percentage of the control $(0.0 \mathrm{MPa})$ within each cultivar. Data were pooled across cultivars.

\begin{tabular}{|c|c|c|c|c|c|c|}
\hline $\begin{array}{l}\text { Drought } \\
(\mathrm{MPa})^{\mathrm{z}}\end{array}$ & $\begin{array}{l}\text { Shoot } \\
\text { dry wt }\end{array}$ & $\begin{array}{c}\text { Absolute water } \\
\text { content }\end{array}$ & $\begin{array}{c}\text { Longest } \\
\text { root length }\end{array}$ & $\begin{array}{c}\text { Root } \\
\text { dry wt }\end{array}$ & $\begin{array}{c}\text { Specific } \\
\text { root length }\end{array}$ & $\begin{array}{l}\text { Root:shoot } \\
\text { dry wt ratio }\end{array}$ \\
\hline & \multicolumn{6}{|c|}{ (\% of the control) } \\
\hline 0.0 & $100.0 \mathrm{a}^{\mathrm{y}}$ & $100.0 \mathrm{a}$ & $100.0 \mathrm{a}$ & $100.0 \mathrm{~b}$ & $100.0 \mathrm{a}$ & $100.0 \mathrm{~b}$ \\
\hline-0.3 & $115.1 \mathrm{a}$ & $91.7 \mathrm{a}$ & $109.9 \mathrm{a}$ & $384.1 \mathrm{a}$ & $34.5 \mathrm{c}$ & $361.7 \mathrm{a}$ \\
\hline-0.6 & $97.3 \mathrm{a}$ & $52.5 \mathrm{~b}$ & $73.7 \mathrm{a}$ & $204.7 \mathrm{~b}$ & $58.2 \mathrm{~b}$ & $262.5 \mathrm{a}$ \\
\hline
\end{tabular}

${ }^{\mathrm{z}}$ Drought was induced by polyethylene glycol 6000 at $0.0,-0.3$, and $-0.6 \mathrm{MPa} ; 1 \mathrm{MPa}=10 \mathrm{bar}$.

${ }^{\mathrm{y}}$ Means followed by the same letter are not significantly different from each other via PDIFF statement of the least square means at $P \leq 0.05$ (SAS version 9.4 ; SAS Institute). 
There were no differences in AWC in the plants grown at -0.3 $\mathrm{MPa}$ compared with those at 0.0 $\mathrm{MPa}$ when data were pooled across cultivars (Table 3 ). As the drought severity increased to $-0.6 \mathrm{MPa}$, AWC decreased to $52.5 \%$ of the control. Among all cultivars, Crystal Bluelinks, Declaration, Penn A-4, and Penn A-1 had a similar AWC that was higher than the other cultivars when data were pooled across PEG concentrations (Table 4). The average AWC of 'Pin-up', 'Alpha', 'Independence', and 'V8' was $91.8 \%$ of the control, significantly higher than 'L-93', '007', and 'Penncross'. Limited differences in AWC were observed among the other cultivars.

No significant difference between the nonstressed and droughtinduced conditions was observed for LRL (Table 2). LRL was $94.5 \%$ of the control when data were pooled across drought conditions (Table 3 ). Significant differences in LRL were observed in the bentgrass cultivars, ranging from $122.9 \%$ of the control in Independence to $71.9 \%$ of the control in Memorial (Table 4). 'Penncross', 'Crystal Bluelinks', and 'Tyee' had a higher LRL than that of 'L-93', 'South Shore', 'Pin-up', 'Bengal', 'Pennlinks II', and 'Memorial'. Although 'SR 1150' had a similar LRL as 'Penncross', 'Crystall Bluelinks', and 'Tyee', but it performed better than 'Bengal', 'Pennlinks II', and 'Memorial'.

RDW was $384.1 \%$ of the control at $-0.3 \mathrm{MPa}, 152.1 \%$ higher than that at 0.0 and $-0.6 \mathrm{MPa}$ (average $=$ $152.4 \%$ of the control) (Table 3 ). Among the cultivars, Independence and Memorial had the highest and lowest RDW, respectively, when data were pooled across drought conditions (Table 4). RDW of 'Alpha' and 'L-93' was similar to that of 'Independence'. Five bentgrass cultivars (Independence, Alpha, L-93, MacKenzie, and SR 1150) had a higher RDW than 'Memorial'.

SRL was reduced at -0.3 and $-0.6 \mathrm{MPa}$ compared with the control, with the highest reduction at -0.3 $\mathrm{MPa}$ (Table 3). All bentgrass cultivars showed a similar level of SRL with an average of $64.3 \%$ of the control (Table 4).

Plants grown at -0.3 and -0.6 MPa had a similar level of RSR (average $=312.1 \%$ of the control $)$ (Table 3$)$. 'L-93' and 'Pin-up' had the highest and lowest RSR, respectively (Table 4). Bentgrass cultivars ranked closely in RSR, with 11 cultivars performed similarly as L-93 and 13 cultivars performed similarly as Pin-up.

All growth parameters were significantly correlated with each other, except SRL and AWC (Table 5). The highest correlation coefficient was observed between RDW and SRL ( $r=$ $-0.69)$, whereas the lowest correlation coefficient was between RSR and SDW $(r=-0.19)$ and between SDW and $\operatorname{RSR}(r=-0.19)$. 'Independence' appeared four times in the top ranking group, followed by 'Crystal Bluelinks' (Table 4). By contrast, 'Cobra 2', 'V8', 'Pennlinks II', 'South shore', and 'Memorial' performed poorly $(\mathrm{TPI}=0)$.

\section{Discussion}

Creeping bentgrass is one of the most common turfgrass species used on golf putting greens and fairways and requires the most intensive management input (including irrigation) of all golf course turfgrass species. Rooting characteristics, including RDW and LRL, are closely related to water uptake. SRL is the ratio between water acquisition (i.e., LRL) and carbohydrate investment (i.e., RDW) (Pérez-Harguindeguy et al., 2013). Plants with a high SRL are generally considered more efficient in water uptake per unit dry weight (Pérez-Harguindeguy et al., 2013). Huang and Fry (1998) reported a higher SRL in the drought tolerant tall fescue cultivar, K-31, than the sensitive one, MIC18. Similar results were also reported by Huang (2001). However, drought tolerance of centipedegrass (Eremochloa ophiuroide), seashore paspalum (Paspalum vaginatum), commmon bermudagrass (Cynodon dactylon), and zoysiagrass (Zoysia sp.) was negatively associated with SRL under both well-watered and drought conditions (Huang et al., 1997). PérezHarguindeguy et al. (2013) suggested that LRL and RDW both need to be taken into consideration when evaluating SRL, as high SRL may be a result of LRL, RDW, or both. Deep rooting is one of the major morphological traits for drought avoidance, indicating a high potential to acquire water from deep soil layers (McCann and Huang, 2008). Plants with deep roots often exhibit low root diameter; therefore, having increased root surface area for high water and nutrient absorption. Plants with low RDW, in general, indicate that they have low penetration to exploit deep soil layers and poor root longevity (Pérez-Harguindeguy et al., 2013). In this study, drought stress enhanced RDW, but did not affect root elongation which may explain the reduction of the SRL (Table 4). Furthermore, SRL was more closely correlated with RDW $(r=-0.69)$ than LRL $(r=-0.19)$ in the present study (Table 5 ).

Our results indicated that SDW was unaffected by drought. However, AWC, an indicator of leaf area, was decreased at $-0.6 \mathrm{MPa}$ (Table 3), which is in agreement with previous research findings that cell expansion is more sensitive to drought than photosynthetic traits, such as chlorophyll content, stomatal regulation, and carbon dioxide assimilation (Pugnaire et al., 1999). This study suggested that the bentgrass leaf was smaller but thicker at $-0.6 \mathrm{MPa}$. Plants often have a reduced leaf number and a smaller leaf surface area when exposed to drought to minimize water requirement and water loss caused by transpiration. Such morphological changes in return contribute to low carbohydrate assimilation, especially under prolonged drought conditions, resulting a deficient energy supply for survival, poststress recovery or both. Zhang et al. (2015) reported thickened cuticles in drought-stressed sugarcane (Saccharum officinarum). Furthermore, the drought resistant sugarcane cultivar, F172, showed higher thickness of the lower epidermal cuticle than the sensitive YL6.

Drought may also influence carbon allocation in plants. For example, RSR was higher in drought-stressed rice (Oryza sativa) compared with the well-watered plants (Xu et al., 2015). Similar results were reported in other crops, including oleander [Nerium oleander (Niu and Rodriguez, 2008)], cotton [Gossypium hirsutum (Pace et al., 1999)], and arabidopsis [Arabidopsis thaliana (Durand et al., 2016)]. Huang and Gao (2000) reported an increased proportion of ${ }^{14} \mathrm{C}$ allocated to the root than shoot in tall fescue cultivars under the soil drying condition, with a greater increase in tolerant cultivars, and a higher proportion in the deeper root. Drought could inhibit or deactivate metabolic activities in shoot tissue 
Table 4. Relative shoot and root growth of 23 creeping bentgrass cultivars grown under drought at the seedling growth stage. Data at -0.3 and $-0.6 \mathrm{MPa}$ were standardized as percentage of the control $(0.0 \mathrm{MPa})$ within each cultivar. Data were pooled across drought levels $(0.0,-0.3$, and $-0.6 \mathrm{MPa})$. Cultivars are ordered according to their turf performance index. ${ }^{\mathrm{z}}$

\begin{tabular}{|c|c|c|c|c|c|c|c|}
\hline Cultivar & $\begin{array}{l}\text { Shoot } \\
\text { dry wt }\end{array}$ & $\begin{array}{c}\text { Absolute } \\
\text { water content }\end{array}$ & $\begin{array}{c}\text { Longest } \\
\text { root length }\end{array}$ & $\begin{array}{c}\text { Root } \\
\text { dry wt }\end{array}$ & $\begin{array}{c}\text { Specific } \\
\text { root length }\end{array}$ & $\begin{array}{l}\text { Root:shoot } \\
\text { dry wt ratio }\end{array}$ & $\begin{array}{c}\text { Turf performance } \\
\text { index }^{\mathrm{y}}\end{array}$ \\
\hline & \multicolumn{7}{|c|}{ (\% of the control) } \\
\hline Independence & $130.5 a-d^{x}$ & $92.0 \mathrm{c}-\mathrm{g}$ & $122.9 \mathrm{a}$ & $454.5 \mathrm{a}$ & $51.5 \mathrm{a}$ & $341.2 \mathrm{ab}$ & 4 \\
\hline Crystal Bluelinks & $136.7 \mathrm{a}-\mathrm{c}$ & $127.0 \mathrm{a}$ & $108.8 \mathrm{ab}$ & $253.2 \mathrm{~b}-\mathrm{f}$ & $60.1 \mathrm{a}$ & 163.8 ef & 3 \\
\hline Declaration & $128.8 \mathrm{a}-\mathrm{d}$ & $123.0 \mathrm{ab}$ & $97.3 \mathrm{~b}-\mathrm{e}$ & $250.3 \mathrm{~b}-\mathrm{f}$ & $54.8 \mathrm{a}$ & $185.2 \mathrm{~d}-\mathrm{f}$ & 2 \\
\hline Alpha & $108.6 \mathrm{~b}-\mathrm{f}$ & $93.3 \mathrm{c}-\mathrm{g}$ & $91.1 \mathrm{~b}-\mathrm{f}$ & $328.1 \mathrm{ab}$ & $65.9 \mathrm{a}$ & $303.9 \mathrm{a}-\mathrm{d}$ & 2 \\
\hline Penncross & 74.5 ef & $58.4 \mathrm{i}$ & $110.9 \mathrm{ab}$ & $212.8 \mathrm{~b}-\mathrm{f}$ & $81.5 \mathrm{a}$ & $305.5 \mathrm{a}-\mathrm{d}$ & 2 \\
\hline Kingpin & $138.5 \mathrm{ab}$ & $95.6 \mathrm{~b}-\mathrm{e}$ & $93.0 \mathrm{~b}-\mathrm{e}$ & $225.9 \mathrm{~b}-\mathrm{f}$ & $54.7 \mathrm{a}$ & $175.6 \mathrm{~d}-\mathrm{f}$ & 1 \\
\hline Pin-up & $125.5 \mathrm{a}-\mathrm{d}$ & $94.8 \mathrm{c}-\mathrm{f}$ & $85.2 \mathrm{c}-\mathrm{f}$ & 150.7 ef & $65.2 \mathrm{a}$ & $126.5 \mathrm{f}$ & 1 \\
\hline Penn A-4 & $121.0 \mathrm{~b}-\mathrm{e}$ & $108.7 \mathrm{a}-\mathrm{c}$ & $90.5 \mathrm{~b}-\mathrm{f}$ & $201.2 \mathrm{~b}-\mathrm{f}$ & $58.3 \mathrm{a}$ & $171.8 \mathrm{~d}-\mathrm{f}$ & 1 \\
\hline Penn A-1 & $109.5 \mathrm{~b}-\mathrm{f}$ & $102.2 \mathrm{a}-\mathrm{d}$ & $94.6 \mathrm{~b}-\mathrm{e}$ & $221.3 \mathrm{~b}-\mathrm{f}$ & $84.0 \mathrm{a}$ & $187.0 \mathrm{~d}-\mathrm{f}$ & 1 \\
\hline Mackenzie & $98.1 \mathrm{~b}-\mathrm{f}$ & $77.7 \mathrm{~d}-\mathrm{i}$ & $92.8 \mathrm{~b}-\mathrm{f}$ & $298.1 \mathrm{~b}-\mathrm{d}$ & $53.7 \mathrm{a}$ & $294.6 \mathrm{a}-\mathrm{e}$ & 1 \\
\hline Putter & $86.2 \mathrm{~d}-\mathrm{f}$ & $67.9 \mathrm{f}-\mathrm{i}$ & $92.1 \mathrm{~b}-\mathrm{f}$ & $215.5 \mathrm{~b}-\mathrm{f}$ & $55.5 \mathrm{a}$ & $288.7 \mathrm{a}-\mathrm{e}$ & 1 \\
\hline Tyee & $84.0 \mathrm{~d}-\mathrm{f}$ & $68.2 \mathrm{e}-\mathrm{i}$ & $106.9 \mathrm{ab}$ & $188.2 \mathrm{c}-\mathrm{f}$ & $75.3 \mathrm{a}$ & $245.6 \mathrm{a}-\mathrm{f}$ & 1 \\
\hline $\mathrm{T}-1$ & $85.7 \mathrm{~d}-\mathrm{f}$ & $75.3 \mathrm{~d}-\mathrm{i}$ & $93.1 \mathrm{~b}-\mathrm{e}$ & $188.3 \mathrm{c}-\mathrm{f}$ & $61.8 \mathrm{a}$ & $237.6 \mathrm{a}-\mathrm{f}$ & 1 \\
\hline V8 & $103.9 \mathrm{~b}-\mathrm{f}$ & $86.9 \mathrm{c}-\mathrm{h}$ & $93.0 \mathrm{~b}-\mathrm{e}$ & $194.9 \mathrm{~b}-\mathrm{f}$ & $70.5 \mathrm{a}$ & $199.9 \mathrm{c}-\mathrm{f}$ & 0 \\
\hline Cobra 2 & $90.7 \mathrm{c}-\mathrm{f}$ & $67.9 \mathrm{f}-\mathrm{i}$ & $94.9 \mathrm{~b}-\mathrm{e}$ & $217.6 \mathrm{~b}-\mathrm{f}$ & $57.3 \mathrm{a}$ & $250.5 \mathrm{a}-\mathrm{f}$ & 0 \\
\hline South Shore & $96.5 \mathrm{~b}-\mathrm{f}$ & $72.0 \mathrm{e}-\mathrm{i}$ & $85.4 \mathrm{c}-\mathrm{f}$ & $169.1 \mathrm{~d}-\mathrm{f}$ & $64.9 \mathrm{a}$ & $197.7 \mathrm{c}-\mathrm{f}$ & 0 \\
\hline Pennlinks II & $88.9 \mathrm{~d}-\mathrm{f}$ & $68.8 \mathrm{e}-\mathrm{i}$ & 78.5 ef & $154.3 \mathrm{ef}$ & $74.6 \mathrm{a}$ & $187.1 \mathrm{~d}-\mathrm{f}$ & 0 \\
\hline Memorial & $71.1 \mathrm{ef}$ & $66.6 \mathrm{~g}-\mathrm{i}$ & $71.9 \mathrm{f}$ & $131.4 \mathrm{f}$ & $77.7 \mathrm{a}$ & $231.8 \mathrm{~b}-\mathrm{f}$ & 0 \\
\hline
\end{tabular}

${ }^{\mathrm{z}}$ Drought was induced by polyethylene glycol 6000 at $0.0,-0.3$, and $-0.6 \mathrm{MPa} ; \mathrm{MPa}=10$ bar.

${ }^{y}$ Turfgrass performance index represents the number of times a cultivar occurred in the top statistical group.

${ }^{\mathrm{x}}$ Means followed by the same letter are not significantly different from each other via PDIFF statement of the least square means at $P \leq 0.05$ (SAS version 9.4 ; SAS Institute).

Table 5. Correlation coefficients $(r)$ among shoot dry weight (SDW), absolute water content (AWC), longest root length (LRL), root dry weight (RDW), specific root length (SRL), and root to shoot dry weight ratio (RSR) of 23 creeping bentgrass cultivars grown under drought at the seedling growth stage. Data at -0.3 and $-0.6 \mathrm{MPa}$ were standardized as percentage of the control $(0.0$ $\mathrm{MPa}$ ) within each cultivar. Data were pooled across drought levels and cultivars. ${ }^{\mathrm{z}}$

\begin{tabular}{llllllr}
\hline & SDW & AWC & LRL & RDW & SRL & RSR \\
\hline SDW & \multirow{2}{*}{1.00} & $0.41^{*}$ & $0.22^{*}$ & $0.27^{*}$ & $-0.30^{*}$ & $-0.19^{*}$ \\
AWC & & 1.00 & $0.40^{*}$ & $0.24^{*}$ & $-0.05^{\text {Ns }}$ & $-0.22^{*}$ \\
LRL & & & 1.00 & $0.53^{*}$ & $-0.19^{*}$ & $0.36^{*}$ \\
RDW & & & & 1.00 & $-0.69^{*}$ & $0.36^{*}$ \\
SRL & & & & & 1.00 & $-0.62^{*}$ \\
RSR & & & & & & 1.00 \\
\hline
\end{tabular}

${ }^{\mathrm{z}}$ Drought was induced by polyethylene glycol 6000 at $0.0,-0.3$, and $-0.6 \mathrm{MPa} ; \mathrm{MPa}=10 \mathrm{bar}$.

*, ss Significant differences and no significant differences at $P \leq 0.05$.

to minimize the use of water and nutrients, whereas metabolic activities in roots are enhanced to improve water and nutrient uptake (GargalloGarriga et al., 2014). In this study, drought stress increased RSR, which was primarily the result of enhanced root growth (Table 4 ). Similarly, RSR was more closely related to $\mathrm{RDW}(r=$ $0.36)$ than SDW $(r=-0.19)$ (Table 5$)$. $\mathrm{Xu}$ and Zhou (2005) and Xu et al. (2010) suggested that such an asymmetric growth trend would diminish or be reversed under severe drought because of a significant reduction in root demand for carbon allocation.

Although differences in the shoot and root growth among the 23 creeping bentgrass cultivars were observed in the present study, the ranking of their relative growth was close (Table 4). Under the drought condition, 'Independence' and 'Crystal Bluelinks' were more drought tolerant (i.e., higher TPI), whereas 'Cobra 2', 'V8', 'Pennlinks II', 'South shore', and 'Memorial' were drought sensitive (TPI $=0)$, and the other 16 cultivars were intermediate between the two contrasting groups.

\section{Literature cited}

Brede, A.D. 2007. 'Alpha' and 'T-1' creeping bentgrass, new cultivars for golf. HortScience 42:1301-1302.

Chai, Q., Z.G. Guo, J.Z. Ren, and Z.B. Nan. 2006. Assessment of drought resistance of Kentucky bluegrass (Poa pratensis) varieties at seedling stage. N.Z. J. Crop Hort. Sci. 34:319-328.

Christians, N. 2011. Fundamentals of turfgrass management. 4th ed. Wiley, Hoboken, NJ.

Durand, M., B. Porcheron, N. Hennion, L. Maurousset, R. Lemoine, and N. Pourtau. 2016. Water deficit enhances C export to the roots in Arabidopsis thaliana plants with contribution of sucrose transporters in both shoot and roots. Plant Physiol. 170:1460-1479.

Fry, J. and B. Huang. 2004. Applied turfgrass science and physiology. Wiley, Hoboken, NJ.

Gargallo-Garriga, A., J. Sardans, M. PérezTrujillo, A. Rivas-Ubach, M. Oravec, K. 
Vecerova, O. Urban, A. Jentsch, J. Kreyling, C. Beierkuhnlein, T. Parella, and J. Peñuelas. 2014. Opposite metabolic responses of shoots and roots to drought. Scientific Rpt. 4:6829.

Govindasamy, R., K. Sullivan, M. Brennan, V. Puduri, B. Clarke, and A. Adelaja. 2007. The New Jersey turfgrass industry economic survey-Executive summary. 19 Apr. 2018. <https://turf.rutgers.edu/ outreach/econsurvexecsummfullreport. pdf $>$.

Hoagland, D.R. and D.I. Arnon. 1950. The water culture method for growing plant without soil. California Agr. Expt. Sta. Circ. No. 347.

Horst, G.L. and N.B. Dunning. 1989. Germination and seedling growth of perennial ryegrass in soluble salts. J. Amer. Soc. Hort. Sci. 114:338-342.

Horst, G.H. and R.M. Taylor. 1983. Germination and initial growth of Kentucky bluegrass in soluble salts. Agron. J. 75:679-681.

Huang, B. 2001. Nutrient accumulation and associated root characteristics in response to drought stress in tall fescue cultivars. HortScience 36:148-152.

Huang, B., R.R. Duncan, and R.N. Carrow. 1997. Root spatial distribution and activity of four turfgrass species in response to localized drought tolerance. Intl. Turfgrass Soc. Res. J. 8:681-690.

Huang, B. and J.D. Fry. 1998. Root anatomical, physiological, and morphological responses to drought stress for tall fescue cultivars. Crop Sci. 38:1017-1022.

Huang, B. and H. Gao. 2000. Root physiological characteristics associated with drought resistance in tall fescue cultivars. . Crop Sci. 40:196-203.

Hughes, A.P., K.E. Cockshull, and O.V.S. Heath. 1970. Leaf area and absolute leaf water content. Ann. Bot. 34:259-265.
McCann, S.E. and B. Huang. 2008. Evaluation of drought tolerance and avoidance traits for six creeping bentgrass cultivars. HortScience 43:519-524.

Mexal, J., J.T. Fisher, J. Osteryoung, and C.P. Reid. 1975. Oxygen availability in polyethylene glycol solutions and its implications in plant-water relations. Plant Physiol. 55:20-24.

Michel, B.E. and M.R. Kaufmann. 1973. The osmotic potential of polyethylene glycol 6000. Plant Physiol. 51:914-916.

National Turfgrass Evaluation Program. 2008. 2003 National bentgrass (putting green) test. Final report NTEP No. 08-8.

Niu, G. and D.S. Rodriguez. 2008. Growth and physiological responses to drought stress in four oleander clones. J. Amer. Soc. Hort. Sci. 133:188-196.

Pace, P.F., H.T. Cralle, S.H.M. El-Halawany, J.T. Cothren, and S.A. Senseman. 1999. Drought-induced changes in shoot and root growth of young cotton plants. J. Cotton Sci. 3:183-187.

Pérez-Harguindeguy, N., S. Díaz, E. Garnier, S. Lavorel, H. Poorter, P. Jaureguiberry, M.S. Bret-Harte, W.K. Cornwelf, J.M. Craine, D.E. Gurvich, C. Urcelary, E.J. Veneklaas, P.B. Reich, L. Poorter, I.J. Wright, P. Ray, L. Enrico, J.G. Pausas, A.C. de Vos, N. Buchmann, G. Funes, F. Quétier, J.G. Hodgson, K. Thompson, H.D. Morgan, H.T.E.R. Steege, M.G.A. van der Heijden, L. Sack, B. Blonder, P. Poschlod, M.V. Vaieretti, G. Conti, A.C. Staver, S. Aquino, and J.H.C. Cornelissen. 2013. New handbook for standardized measurement of plant functional traits worldwide. Austral. J. Bot. 61:167-234.

Pugnaire, F.I., L. Serrano, and J. Pardos. 1999. Constraints by water stress on plant growth, p. 271-313. In: M. Pessarakli (ed.). Handbook of plant and crop stress. 2nd ed. Marcel Dekker, New York, NY.
Reicher, Z., C. Bigelow, A. Patton, and T. Voigt. 2006. Establishing turfgrass areas from seed. 3 Apr. 2018. <https://www. extension.purdue.edu/extmedia/AY/ AY-3-W.pdf>.

Salaiz, T.A., R.C. Sherman, T.P. Riordan, and E.J. Kinbacher. 1991. Creeping bentgrass cultivar water use and rooting responses. Crop Sci. 31:1331-1334.

Wherley, B.G., P. Skulkaew, A. Chandra, A.D. Genovesi, and M.C. Engelke. 2011. Low-input performance of zoysiagrass (Zoysia sp.) cultivars maintained under dense tree shade. HortScience 46:10331037.

Xu, W., K. Cui, A. Xu, L. Nie, J. Huang, and S. Peng. 2015. Drought stress condition increases root to shoot ratio via alteration of carbohydrate partitioning and enzymatic activity in rice seedlings. Acta Physiol. Plant. 37:1-9.

$\mathrm{Xu}, \mathrm{Z}$. and G. Zhou. 2005. Effects of water stress and nocturnal temperature on carbon allocation in the perennial grass, Leymus chinensis. Physiol. Plant. 123:272280.

Xu, Z., G. Zhou, and H. Shimizu. 2010. Plant responses to drought and rewatering. Plant Signal. Behav. 5:649-654.

Zhang, Q., S. Wang, and K. Ruen. 2011. Salinity tolerance of 12 turfgrasses in three germination media. HortScience 46:651654.

Zhang, F.J., K.K. Zhang, C.Z. Du, J. Li, Y.X. Xing, L.T. Yang, and Y.R. Li. 2015. Effect of drought stress on anatomical structure and chloroplast ultrastructure in leave of sugarcane. Sugar Tech 17:41-48. 